\title{
RUINY, WSZĘDZIE RUINY: CZARNOBYL I ARCHEOLOGICZNY WYMIAR DZIEDZICTWA NIEDAWNEJ PRZESZLOŚCI
}

SŁowa kluczowe: Czarnobyl, archeologia współczesności, dziedzictwo, ruiny, materialność, pamięć

KEYwORDs: Chernobyl, contemporary archaeology, heritage, ruins, materiality, memory

\section{WSTĘP}

26 kwietnia 2016 roku minęło 30 lat od katastrofy w Czarnobylu. W związku z pełną rocznicą tego wydarzenia, sporo pisało i mówiło się w mediach, zarówno krajowych jak i zagranicznych, o przeszłości i współczesności Strefy Zero (np. Andrusieczko 2016; Oliphant 2016). To również dobra okazja, do krótkiej refleksji nad ,archeologicznym wymiarem” tej katastrofy i samego dziedzictwa związanego z eksplozją w elektrowni; szerzej zaś, znaczenia, funkcji i „bycia” ruin niedawnej przeszłości we współczesnych krajobrazach.

Nie natrafiłem w polskiej literaturze archeologicznej na jakikolwiek komentarz poświęcony wydarzeniom czarnobylskim. Dlatego też pretekstem niniejszej dyskusji jest refleksja nad filmem dokumentalnym pt. Czarnobyl - Wstęp Wzbroniony (2015) według scenariusza i reżyserii Armina Kurasza. Prowadzącym jest dziennikarz i eksplorator Jacek Podemski. Obraz, jak tytuł jasno sugeruje, dokumentuje i przedstawia bliżej widzowi Czarnobylską Strefę Wykluczenia kilkanaście lat po wybuchu reaktora w bloku 4. Chociaż nie ma w nim mowy o archeologii, materialnym dziedzictwie ostatnich dekad etc. to w artykule tym sugeruję, iż Czarnobyl - Wstęp Wzbroniony to dokument do szpiku kości ,archeologiczny”, poruszający problematykę, która stanowi samo sedno refleksji nad XX-wiecznymi pozostałościami (por. Buchli, Lucas 2001; Holtorf, Piccini 2009; Harrison, Schofield 2010; Olivier 
2013; Olsen, Pétursdóttir 2014; Schlanger i in. 2016) (ryc. 1). To w końcu przykład ,archeologii ruin” (an archaeology of ruins; por. Pétursdóttir, Olsen 2014).

Trwanie, przemijanie, materialność, pamięć, naturokulturowy wymiar dziedzictwa, konsekwencje tzw. płaskiej ontologii to jedne z kluczowych problemów podejmowanych $\mathrm{w}$ archeologicznych dyskusjach nad ruinami nowoczesności. W ich ramach - upraszczając zagadnienie - nie chodzi o poznanie historii danego miejsca. Tutaj zniszczone budynki nowoczesności nie są metaforą skończonej, minionej przeszłości. Raczej pokazuje się, iż relikty przeszłości są nierozerwalną składową współczesności i aktywnie je współtworzą. Materialność rzeczy i całych krajobrazów są tutaj kluczowym elementem. To właśnie fizyczność, twarda materia mają oferować inną optykę badawczą; prowokować archeologów do stawiania odmiennych pytań niż np. historycy, antropolodzy czy też kulturoznawcy. Jak to trafnie ujmują Póra Pétursdóttir z Bjørnarem Olsenem (2014: 9; tłumaczenie autora):

To materialne trwanie przeszłości ponadto reprezentuje formę pamięci [...]; pamięci, niemniej jednak, która nie 'spogląda wstecz' z perspektywy współczesności w przeszłość jak to jest ze świadomą, trwałą (recollective) pamięcią, lecz jest skierowana przed siebie i pracuje we właściwy dla siebie sposób z perspektywy przeszłości w teraźniejszość [...]. I w przeciwieństwie do tego, co zwykle jest uważane, wielorakie i ogromnie zróżnicowane oraz wielowarstwowe (palimpsestal) asamblaże [...] znanych i nieznanych, użytecznych i porzuconych przeszłości powstałych z tego zebrania konstytuują realne środowiska pamięci. Innymi słowy, to są środowiska, które umożliwiają alternatywne materialne i niezamierzone wspomnienia [...], które mogą fundamentalne różnić się od tych, które odnoszą się do kontrolowanego i rozmyślnego przypominania, które niemniej jednak chroni trwanie, czy też samoistną transmisję, przeszłości w teraźniejszość.

Czarnobyl - Wstęp Wzbroniony wydaje się interesującym przykładem łączącym w sobie archeologiczne zainteresowanie ruinami niedawnej przeszłości i szerszą społeczną fascynacją opuszczonymi krajobrazami. W związku z faktem, iż dzieło A. Kurasza wpisuje się w popularny ostatnimi czasy trend miejskiej eksploracji (urbex), to najpierw zasygnalizuję kluczowe powiązanie między archeologią współczesności a urbexem. Wyeksponowanie wspólnej płaszczyzny między archeologią a tym, co prezentuje film pozwoli na krytyczne omówienie samego dokumentu. Następnie podejmę zagadnienie postrzegania Czarnobyla jako „Pompejów naszych czasów". Poruszana w tym tekście problematyka ruin nowoczesności zmierza do konkluzji, iż czasem „najciemniej jest pod latarnią”. Słowem, archeolodzy skupiając przez dziesięciolecia uwagę na pradziejowym dziedzictwie 


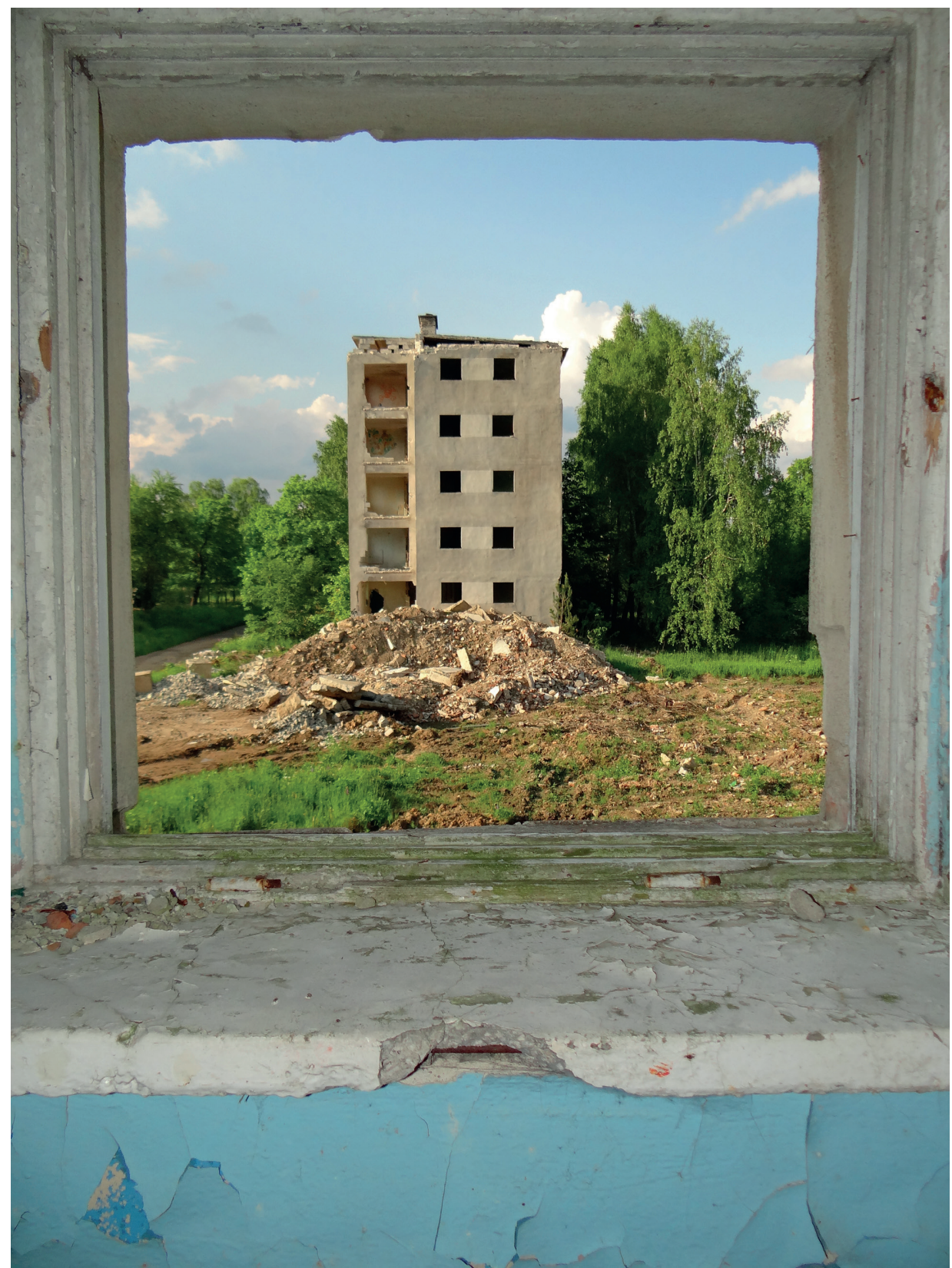

Ryc. 1. „Ruiny, wszędzie ruiny”: jeden z ostatnich zachowanych sowieckich bloków w Kłominie (fot. D. Kobiałka). 
nie dostrzegali kulturowego, społecznego, i siłą rzeczy, „archeologicznego” wymiaru dziedzictwa niedawnej przeszłości (por. również Kajda, Kostyrko 2016).

Można wręcz zasugerować, iż XX-wieczne ruiny mogą być w pewnych kontekstach ważniejsze (wartościowsze) od tych pradziejowych (antycznych), gdyż te pierwsze są częścią nadal żywych wspomnień. Dla jeszcze wielu ludzi to fragment ich życia, część żywej pamięci; jest to w bardzo dosłownym znaczeniu „nasze dziedzictwo”. Z tego też powodu za ilustracje niniejszego tekstu posłużą przykłady radzieckich ruin z terenów dzisiejszej Polski.

\section{URBEX JAKO FORMA ARCHEOLOGII WSPÓLCZESNOŚCI}

Zbitka urbex to neologizm pochodzący od pierwszych liter angielskich słów urban i exploration. W wolnym thumaczeniu urbex to „miejska” (urban) „eksploracja" (exploration) opuszczonych budynków, czasem całych krajobrazów zwykle związana z dziedzictwem XX. i XXI-wiecznym. Ta forma osobistego doświadczania przeszłości stała się niezwykle popularna na przestrzeni ostatnich 20 lat (np. Solis 2005; Paiva 2008). Jest to częsty sposób zwiedzania, dokumentowania miejsc i krajobrazów na Wyspach Brytyjskich oraz w Stanach Zjednoczonych (ryc. 2).

Należy jednak zaznaczyć, iż termin ten jest nieco mylący ponieważ obejmuje eksplorację, zwiedzanie wszelkich opuszczonych i zaniedbanych miejsc, nie tylko tych znajdujących się w miastach. Również w Polsce dostrzegalne jest zwiększone zainteresowanie taką formą kontaktu z materialną przeszłością. Świadczą o tym coraz liczniejsze artykuły ukazujące się w takich mediach jak Gazeta Wyborcza (np. Gołębiowska 2015), na serwisach internetowych np. TVN24 (np. Barriga 2015), a także programy telewizyjne (Łowcy Przygód czy też Wstęp Wzbroniony).

Shannon Lee Dawdy (2010) w artykule pt. Clock punk anthropology and the ruins of modernity zwraca uwagę na powszechną ostatnimi czasy fascynację, lub też nawiązując do koncepcji Michaela Shanksa (2012) - „archeologiczną wyobraźnię", miejscami opuszczonymi, ruinami, motywem końca świata, dystopii (Edensor 2005; Andreassen i in. 2010; Fowler 2015). Przejawem tego społecznego fenomenu jest m.in. ubrex. $\mathrm{Z}$ drugiej strony, składową procesu jest również część środowiska archeologicznego, które dostrzegło ruiny nowoczesności jako potencjalnie ważne miejsca (np. Olsen, Pétursdóttir 2014; Kobiałka i in. 2015a). Tutaj wręcz urbex jawi się jako metoda badawcza, jako sposób myślenia i doświadczania dziedzictwa (np. Pétursdóttir 2012a; 2012b; Kobiałka 2014). Idąc dalej tym tokiem myślenia, urbex może być traktowany jako przejaw ,archeologicznej wyobraźni”, jako sposób kontaktu i myślenia o niedawnej przeszłości. Jest to forma refleksji, dokumentacji 


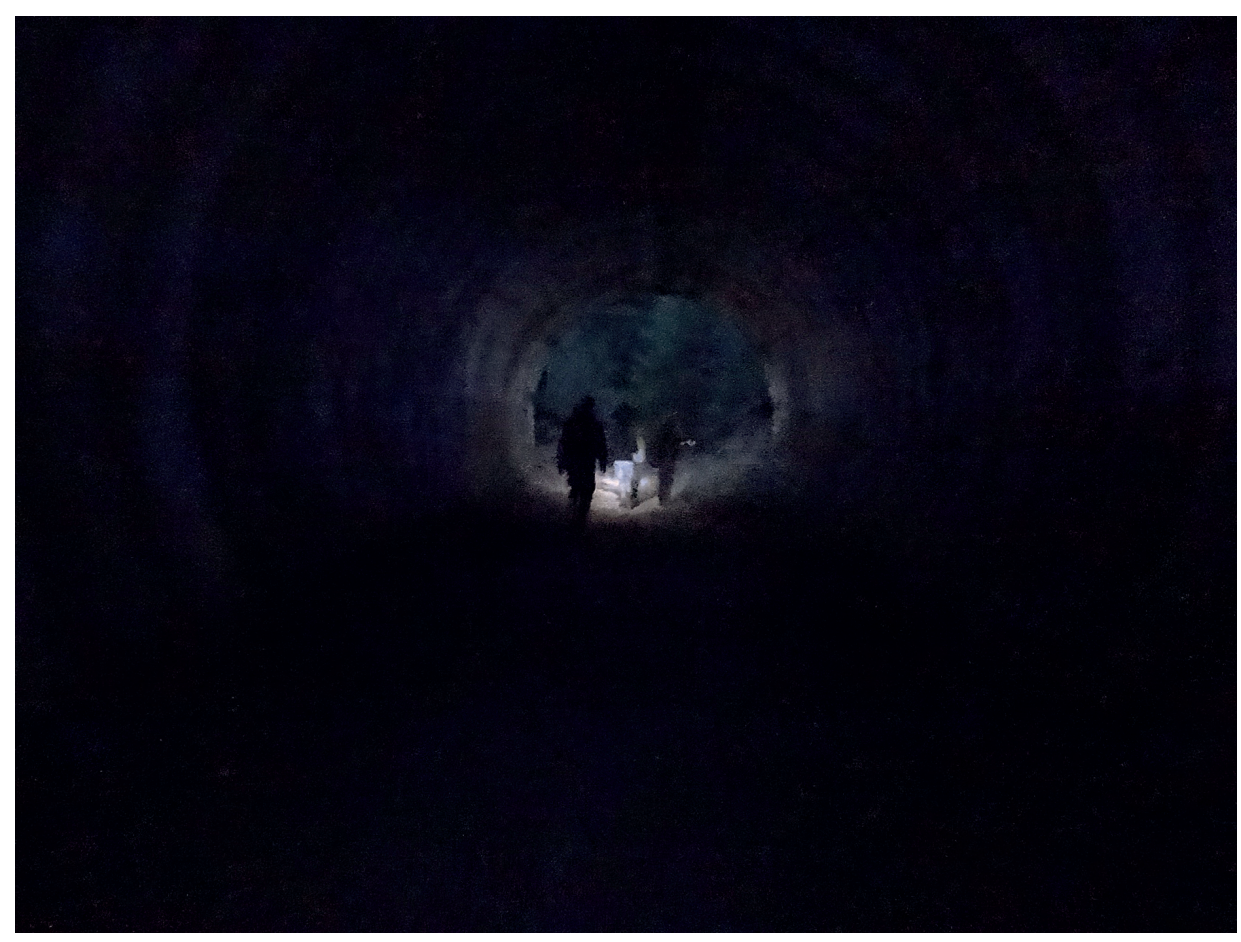

Ryc. 2. Między reprezentacją a prezentacją doświadczenia: eksplorując sowieckie ruiny w Pstrążu (fot. D. Kobiałka).

ruin nowoczesności i pisania o materialnym wymiarze świata (por. Kobiałka 2016). W rzeczy samej, w podobnym kierunku szła myśl S.L. Dawdy (2010: 767; tłumaczenie autora):

Kolejnym współczesnym fenomenem społecznym wskazującym na zwrot archeologiczny w kulturze popularnej jest ruch miejskiej eksploracji (UrbEx) [...]. Adepci eksplorują opuszczone przestrzenie i modernistyczne ruiny współczesnych miast, przeszukując kanały ściekowe, fabryki, parki rozrywki i szkoły. Podczas gdy działania te są zwykle nielegalne (minimalnie łamiąc prawo własności), większość miejskich eksploratorów robi jedynie zdjęcia i publikuje je na blogach. Inni czasem zbierają pamiątki i nazywają siebie ,archeologami industrialnymi”, widocznie będąc nieświadomymi ich akademickich odpowiedników. Najbardziej prominentnymi miejskimi eksploratorami są artyści, którzy doceniają u siebie zdolność dostrzegania tego, co społeczeństwo przegapiło w tych zapomnianych przestrzeniach. Są oni podziemnymi flâneurami, bratnimi duszami Waltera Benjamina, który sam był zaabsorbowanym czytelnikiem fantastyczno-naukowej utopii Charlesa Fouriera. 
Podążając powyższym tokiem myślenia można powiedzieć, że archeologiczna refleksja nad opuszczonymi przestrzeniami nie musi sprowadzać się do odkrywania przeszłości danych miejsc jak np. dokładny wygląd rosyjskich bloków mieszkalnych w Czarnobylu w momencie eksplozji reaktora w bloku 4. Ruiny nowoczesności są intrygujące ze względu na swój niezależny ontologiczny wymiar, na - można by wręcz powiedzieć - swój „materialny ciężar”. Opuszczone przestrzenie nie czekają na naszą interpretację i historyzację. Jak to kapitalnie opisuje P. Pétursdóttir na przykładzie własnych studiów nad ruinami przemysłowymi w Eyri (Islandia) związanymi z połowem śledzia (2012b: 585; tłumaczenie autora):

To raczej betonowa obecność i ciężar tego miejsca oraz fragmentaryczna, niekoherentna pamięć, którą rzeczy podtrzymują wpłynęły na mnie. Nie było to po prostu tak, iż to miejsce, te rzeczy, zapachy i dźwięki dodały nowe i wartościowe aspekty do historii, o której czytałam, czy też inne historie związane z połowem śledzia, lecz raczej tak, iż ich „efekty obecności” [...] zasugerowały inną drogę pamiętania tej przeszłości. Nie przeciw-historia lecz coś w przeciwieństwie do historii; wspomnienia ruin [ruin memories], które już tam były i w żadnym wypadku nie czekały na moją interpretację czy też historyzację.

Dziesiątki godzin spędzonych na eksploracji różnych miejsc, setki kilometrów przejechanych w ich poszukiwaniu, wykonanie do tego momentu około kilku, a może nawet kilkunastu tysięcy zdjęć zrujnowanych fabryk, bloków, koszar, szpitali, zakładów pracy, itd., itd. - wszystko to w celu „doświadczania”, bezpośredniego kontaktu, multisensorycznego doznania, „bycia” z dziedzictwem. Chodzi mi w tym miejscu zatem nie tyle o poznanie „historii” Czarnobyla, a szerzej, pozostałości niedawnej przeszłości w Polsce, ale o tę materialną manifestację, pamięć i ich trwanie. To, co czyni zniszczone przestrzenie nowoczesności tak interesującymi to właśnie fakt, iż - mówiąc nieco tautologicznie - „są ruinami”. O ich historiach, o ich przeszłości wiemy wystarczająco wiele. Namysł archeologiczny nad takimi materialnymi reliktami - jak sugeruje islandzka badaczka - ma zmierzać nie tyle do pisania „mikrohistorii”, „przeciw-historii”, ale czegoś zgoła odmiennego: do „archeologii ruin”. Takie podejście ma duże znaczenie w ogólniejszej refleksji nad dziedzictwem. W ten sposób niniejszy tekst wpisuje się w szerszą dyskusję nad nowymi materializmami (Witmore 2014), nad podejściem, które stara się - upraszczając całą sprawę - „doświadczyć świata poza tekstem”.

Jestem miłośnikiem urbexu, aktywnej eksploracji (zwiedzania i dokumentowania) niedawnej przeszłości. Jest to dla mnie sposobność naocznej obserwacji procesów związanych z powstawaniem i transformacjami materii. Słowem, urbex jest formą doświadczania heritage in the making. To refleksja 
dotycząca jego physis. W końcu, urbex to forma poszukiwań w zakresie archeologii współczesności. Film A. Kurasza również przedstawia proces powstawania dziedzictwa, ukazuje jak trwa i powoli przemija biorąc za studium przypadku ruiny związane z katastrofą czarnobylską.

\section{WSTĘP WZBRONIONY JAKO SPOSÓB DOKUMENTACJI (I DOŚWIADCZANIA) RUIN NOWOCZESNOŚCI}

Wstęp Wzbroniony to program telewizyjny, gdzie główny prowadzący J. Podemski eksploruje opuszczone i zapomniane miejsca. Jest on pokłosiem coraz popularniejszej w naszym kraju społecznej fascynacji miejscami zapominanymi, opuszczonymi; mówiąc najogólniej, ruinami nowoczesności. Na stronie internetowej programu można przeczytać: „Zapraszamy na niezwykłą wyprawę do świata Urban Exploration" ". Do tej pory ukazały się dwa sezony programu, gdzie każdy z nich składa się z ośmiu odcinków.

Wśród miejsc eksplorowanych przez J. Podemskiego były relikty Międzyrzeckiego Rejonu Umocnionego, sowieckie ruiny w Legnicy, podziemia szczecińskiej stoczni, aż po kanały wykorzystywane przez Polaków walczących w Powstaniu Warszawskim, by wymienić tematykę jedynie kilku odcinków. Kontynuacją fascynacji przestrzeniami opuszczonymi jest dokument o Czarnobylu. Warto zaznaczyć, iż są to miejsca, które prawie w ogóle nie zostały dostrzeżone jako warte bliższej archeologicznej analizy; tak jakby były to krajobrazy pozbawione własnych archeologii (por. Kobiałka i in. 2015a; 2015b).

„Mam wrażenie, że Czarnobyl to dziwne, wręcz magiczne miejsce” - tymi słowami J. Podemski zaprasza widzów na eksplorację Czarnobylskiej Strefy Wykluczenia (ryc. 3-4). Technicznie i merytorycznie film jest bardzo dobrze skonstruowany. Sama narracja również jest dynamiczna gdyż biegnie dwutorowo. To znaczy, z jednej strony widzimy J. Podemskiego, który podczas eksploracji kolejnych budynków w Prypeci opowiada o tym, co dostrzega, czego doświadcza, jaka kryje się historia za daną ruiną. Z drugiej strony, mamy do czynienia z lektorem kreślącym szersze tło historyczne dotyczące ludzi, rzeczy i miejsc oglądanych przez widza. Eksploracja Prypeci to forma rekonesansu badawczego, która została poparta wieloma godzinami kwerend archiwalnych. W filmie wykorzystane są m.in. lokalne materiały z Archiwum Elektrowni Atomowej Czarnobyl (zdjęcia i filmy); takie działania to również standardowa praktyka stosowana przez archeologów XX wieku (np. Pétursdóttir 2012a). Kapitalne ujęcia pozwalają samemu do pewnego stopnia „doświadczyć" Czarnobyla. Należy także wspomnieć o dokumentacji fotogra-

\footnotetext{
${ }^{1}$ Por. http://www.tvnturbo.pl/programy/wstep-wzbroniony,10994.html (dostęp: 1.02.2017).
} 


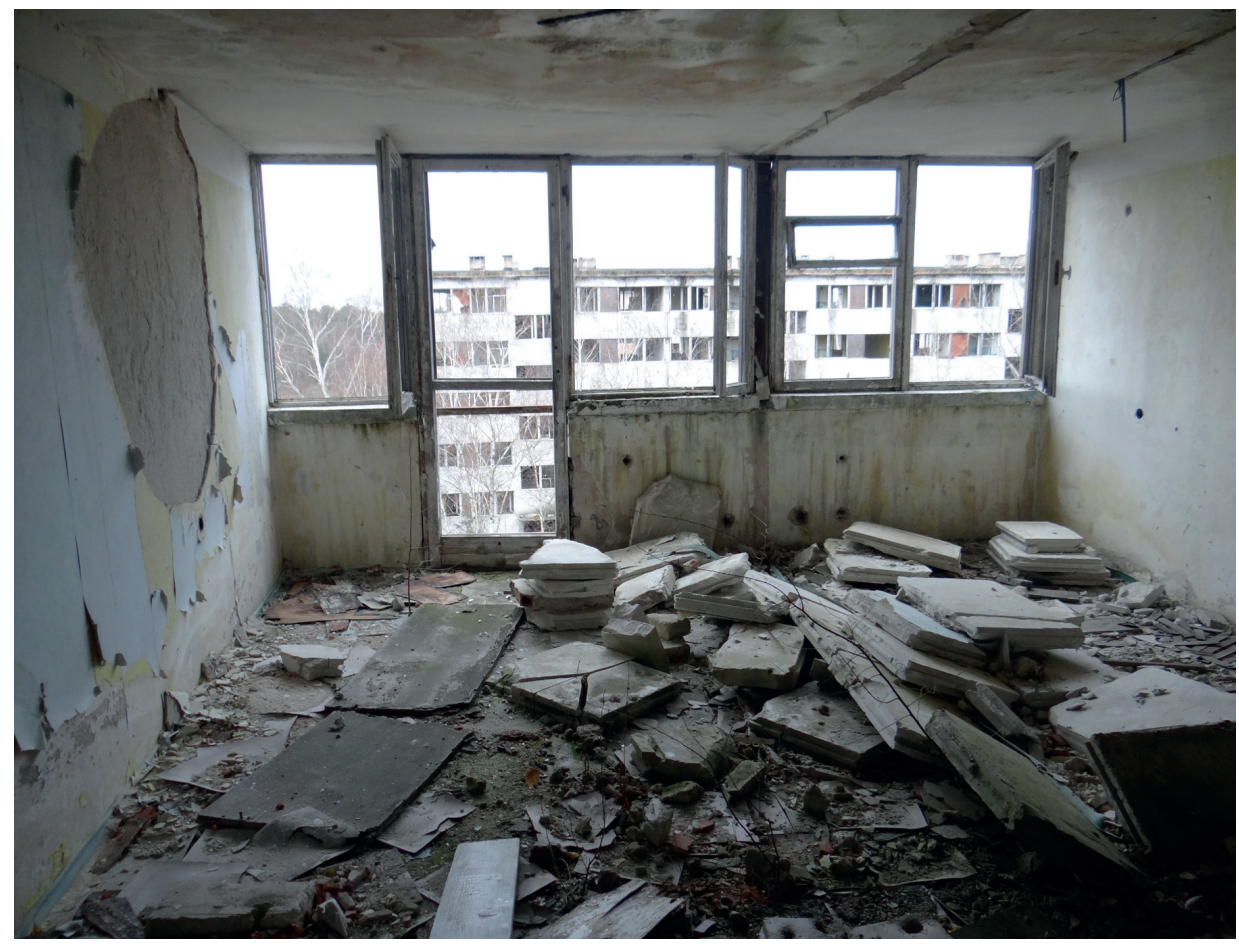

Ryc. 3. Pstrąże nazywane jest czasem polską Prypecią ze względu na ruiny sowieckiego garnizonu: wewnątrz jednego z bloków (fot. D. Kobiałka).

ficznej i video wykonanej przy wykorzystaniu drona (Hanus 2015). W końcu, w kontekście archeologii współczesności, rozmowy (wywiad etnograficzny) i żywa pamięć (wspomnienia) to jedne $\mathrm{z}$ najważniejszych kategorii materiałów badawczych (por. Harrison, Schofield 2010), tak było przy produkcji Wstępu Wzbronionego.

W filmie J. Podemski rozmawia z ludźmi pracującymi w elektrowni w dniu eksplozji. Takim człowiekiem jest Sergey Akulinin, który na własnej skórze doświadczył tegoż feralnego 26 kwietnia 1986 roku. To też jest najbardziej przejmujący fragment dokumentu. Widzimy, jak dziennikarz i Sergey rozmawiają, następnie wchodzą na trzecie piętro jednego ze zrujnowanych bloków w Prypeci. Jak się okazuje, to mieszkanie samego Sergeya: zakurzone dziecięce zabawki, zniszczone meble, okna bez szyb, tapeta odchodząca od ścian. On z rodziną tam żył, to jego ruiny, relikty (z) życia. Scena zapiera dech w piersiach. Te zniszczone zabawki przywołują u rozmówcy wspomnienia z 1986 roku. To - by użyć pojęcia Laurenta Oliviera (2011) - „materialne wspomnienia” (material memories), które rzeczy podtrzymują w sobie (ryc. 5), fragmentaryczne, niepeł- 


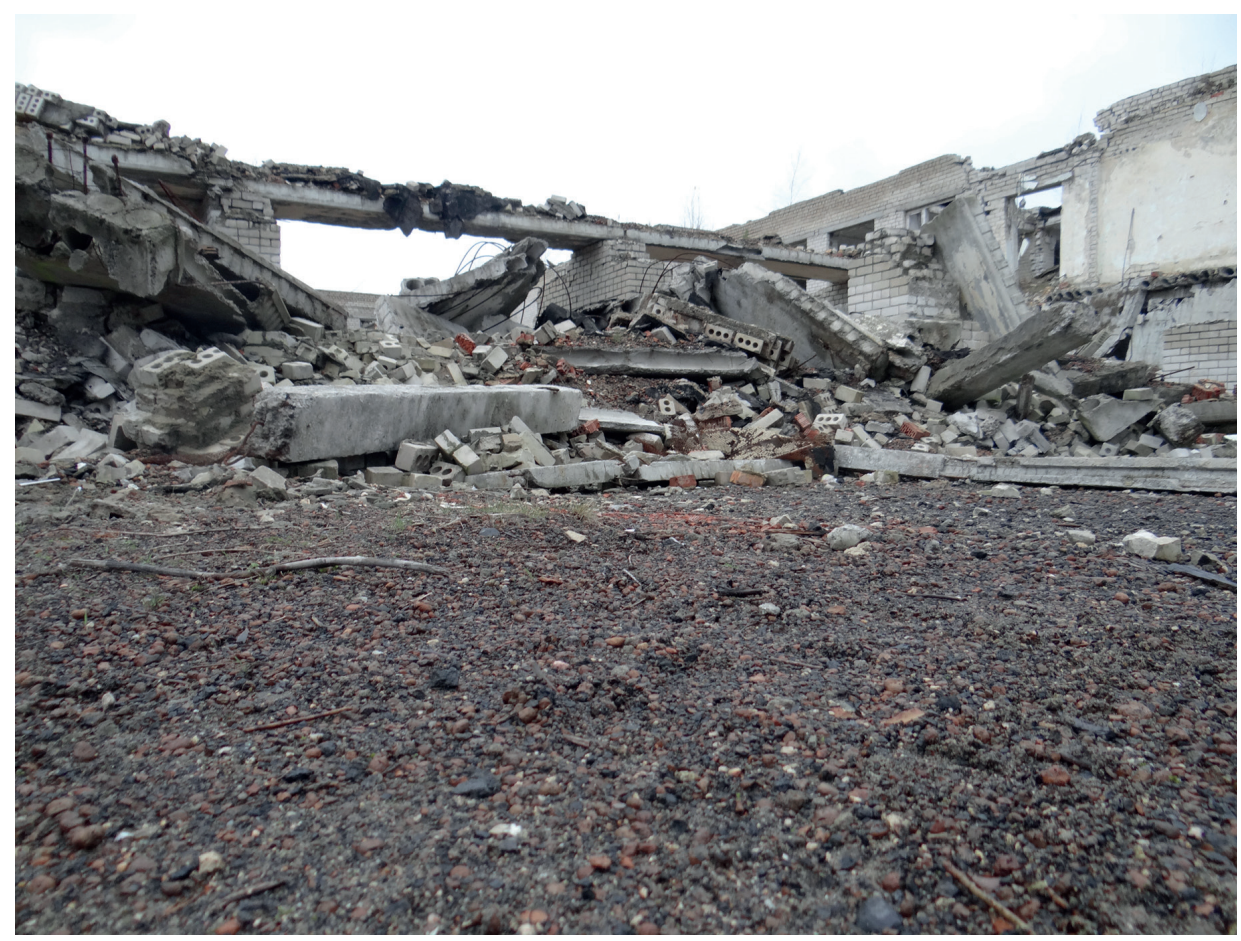

Ryc. 4. Z każdym rokiem sowieckich ruin w Polsce jest coraz mniej: relikty jednego z budynków w Pstrążu (fot. D. Kobiałka).

ne, zamazane skrawki (z) niedawnej przeszłości. Widzimy doskonale, jak to, co społeczne i to, co materialne współtworzy dziedzictwo.

Oglądając dokument o Czarnobylu na myśl nieodparcie przychodzą obrazy dialektyczne Waltera Benjamina (2010) jako te niedyskursywne i efemeryczne iluminacje danego momentu, pewnego specyficznego miejsca. To - mówiąc inaczej - forma szoku, którego od czasu do czasu doświadczamy (por. Kusiak 2013). To świat poza dyskursem, doświadczenia wymykające się językowi, Czarnobyl to materialny obraz dialektyki. Kilka z jej aspektów jest zauważalnych w trakcie oglądania dokumentu. Mowa jest na przykład o niewyobrażalnej katastrofie: Prypeć, prawie 50-tysięczne miasto po wybuchu reaktora wyludniło się w parę godzin; już zapewne na wieki. Niemniej jednak, pobliskie miasto Sławutycz żyje i dobrze prosperuje „dzięki” katastrofie; napędzała i nadal napędza ona lokalną ekonomię. Zatem, jedna ruina pociąga za sobą powstawanie czegoś zupełnie nowego. Inny przykład, widzimy pozostałości szpitala, przedszkola, bloki mieszkalne, wesołe miasteczko z ikonicznym diabelskim kołem, czy też zakłady Jupiter w Prypeci. Można odnieść wrażenie, iż nie są to relikty 


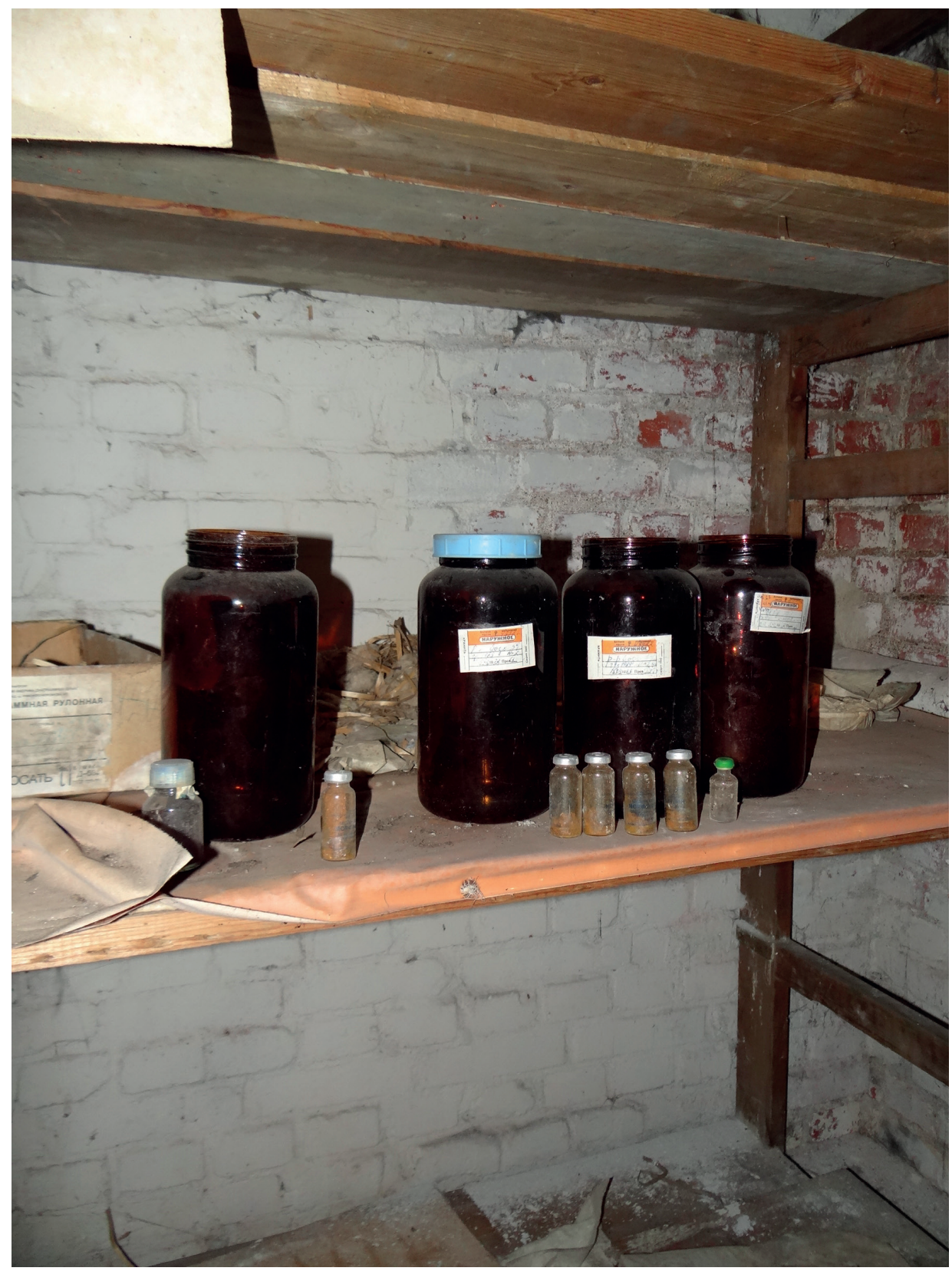

Ryc. 5. „Materialne wspomnienia”: w podziemiach sowieckiego szpitala w Legnicy nazywanej czasem również „Małą Moskwą” (fot. D. Kobiałka). 
minionej epoki. Są one zawieszone jakby między życiem a śmiercią, przeszłością a współczesnością, między materią a efemerycznymi społecznymi wspomnieniami. Materialne pozostałości Czarnobyla w tym sensie są „,szokujące”, przywołują sprzeczne odczucia; takie niejednoznaczne, „niedyskursywne” mają być Benjaminowskie obrazy dialektyczne. Bez dwóch zdań, gdyby W. Benjamin dzisiaj pisał swoje Pasaże, to „musiałyby” się w nich pojawić ruiny Prypeci jako materializacja kondycji społeczeństwa końca XX wieku.

Z perspektywy współczesnej refleksji nad dziedzictwem, należy niestety zaznaczyć, iż film powiela utarte modernistyczne rozróżnienie na: kultura - natura. Rzecz jasna, celem dokumentu nie było zabranie głosu w ramach krytycznych studiów nad dziedzictwem. Jednak analizując go z archeologicznego punktu widzenia, należy o tych aspektach również wspomnieć. Już na początku filmu słyszymy, iż to człowiek próbował opanować miejscową naturę. Dzisiaj to z kolei natura odbiera, odzyskuje to, co człowiek rzekomo jej zabrał wznosząc elektrownię w Czarnobylu.

Jednak, jak ukazują to kapitalne zdjęcia Michała Rajewskiego i Filipa Jurzyka ,aurę" Czarnobyla tworzą nie tylko ruiny elektrowni, opuszczona Prypeć, porzucone i zardzewiałe pojazdy itd. Na fotografiach nie widzimy jedynie „kultury”, tego, co człowiek zbudował w Czarnobylu. Zasadniczą składową krajobrazu są drzewa, mchy, krzaki, rośliny, suche liście, zabłąkane psy, inne zwierzęta. To nie są dwa niezależne porządki, które można oderwać od siebie i analizować osobno. Mówiąc wprost, to, co kulturowe i to, co naturalne kształtuje to miejsce na równych, ,symetrycznych" zasadach. Takie założenie jest jednym z fundamentów „płaskiej ontologii”, według której człowiek jest zaledwie jednym z bytów tworzących środowisko (Harman 2011). Zgodnie z tym, bez drzew, krzaków, traw, mchów i innych roślin wrastających w każdą możliwą ruinę w Prypeci to miejsce wyglądałoby zupełnie inaczej. Owe - jakby to ujął Bruno Latour (2011) - ,,nie-ludzkie kolektywy” nie tylko wpływają na wizerunek tego krajobrazu, one go współkreują. Są częścią ontologii Czarnobyla.

I nie jest ironią losu, iż katastrofa (wydarzenie spowodowane przez człowieka, zatem wydarzenie „kulturowe”) skończyło się stworzeniem rezerwatu dzikiej przyrody w tej części Europy. Niektórzy badacze postulują, chyba słusznie, by o takich powiązaniach myśleć jako o „naturokulturach” (Harraway 2003) (ryc. 6).

\section{Czarnobyl: Pompeje naszych czasów?}

Problematyka związana z katastrofą w Czarnobylu, czy też ostatnio z wydarzeniami w Fukushimie oraz zagadnienia postrzegania odpadów radioaktywnych jako dziedzictwa czasów współczesnych od niedawna pojawiają się w dyskursie archeologicznym (np. Olivier 2013; Holtorf, Högberg 2013; 2014; 


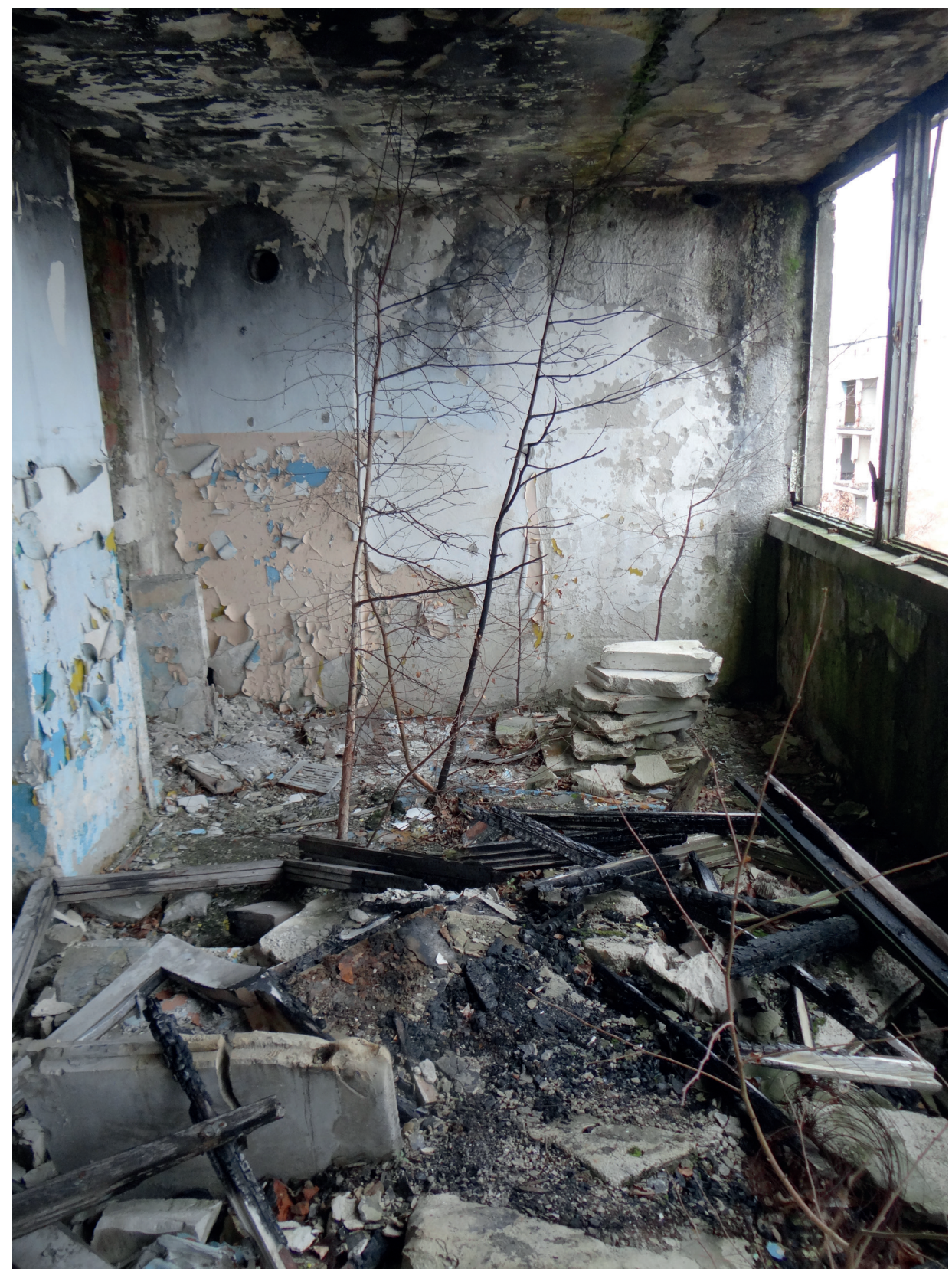

Ryc. 6. „Natura” na czwartym piętrze w jednym z bloków w Pstrążu (fot. D. Kobiałka). 
Brooks 2016; Schlanger i in. 2016). Jednym z nielicznych badaczy, którzy myśleli o Czarnobylu i Fukushimie z perspektywy archeologicznej był L. Olivier (2013). Dla L. Oliviera oba wypadki to „wydarzenia archeologiczne”. Ich konsekwencje będą miały materialny wpływ na lokalny krajobraz przez tysiące lat. Obie katastrofy to doskonały przykład „długiego trwania”, tego jak pewne wydarzenia wpływają na przestrzenie przez setki pokoleń. Jak zauważa francuski archeolog (Olivier 2013: 126; thumaczenie autora):

Trudno przewidzieć co stanie się z Czarnobylem i Fukushimą w trakcie wieków i millenniów, które nadejdą, jednak jest oczywistym, że radioaktywne skażenie, które spowodowały, będzie miało długofalowy wpływ na ludzkie zamieszkanie tych miejsc, jak i ogromnych terenów wokół nich. I ponieważ nie mamy możliwości poznania dhugoterminowych konsekwencji katastrof tego rodzaju nuklearnych wypadków to stanowią one główne wydarzenia archeologiczne naszych czasów. Oczywiście, jako strefy niezamieszkałe obecnie przez człowieka, Czarnobyl i Fukushima stały się współczesnymi Pompejami. Prypeć już jest niezwykłym reliktem sowieckiego miasta $\mathrm{z}$ lat 1980., które jest doskonale nienaruszone, i którego archeologiczna wartość z pewnością będzie wzrastać wraz z upływem czasu. Wkrótce będzie się trzeba zająć tym, czym Prypeć jest: wyjątkowym dwudziestowiecznym stanowiskiem archeologicznym, które musi być chronione.

Porównanie Czarnobyla i Fukushimy z rzymskim miastem pojawia się również $w$ innych archeologicznych opracowaniach poświęconych obu miejscom. Ostatnio Nathan Schalnger wraz z Laurentem Nespoulousem i Jean-Paulem Demoule pisali o ruinach w Fukushimie jako Pompejach naszych czasów (2016: 423; thumaczenie autora):

Podczas, gdy w przypadku Pompejów zarówno nagła katastrofa, jak i trauma już dawno przeminęły pozostawiając nam tylko cudowne skrawki codziennego życia w odległej przeszłości, to w przypadku Fukushimy zarówno anonimowe zagrożenie promieniowania, jak i widma winy, bez dwóch zdań, pozostaną na naszym pokoleniu i wiekach, które nadejdą. Więc, jeśli Pompeje są tym antycznym miastem, gdzie po raz pierwszy przeszłość stała się ożywiona (przynajmniej w naszej zachodniej, kulturowej i naukowej świadomości), Fukushima byłaby tą nowoczesną ruiną, gdzie przyszłość - która czeka na nas wszystkich - po raz pierwszy ukazała się w tak wyraźny sposób.

W końcu, niedługo ma ukazać się rozprawa doktorska Roberta Maxwella z Uniwersytetu w Sydney poświęcona m.in. archeologii Czarnobyla. Również i on opisuje Prypeć jako „swoje Pompeje” (por. Brooks 2016). Takie porównania niosą za sobą pewne uproszczenia.

Należy jasno podkreślić, iż Pompeje, Czarnobyl, Fukushima to nie miejsca, w których czas się zatrzymał. To nie przykłady tzw. ,przesłanki pompe- 
jańskiej”, czyli przeświadczenia, iż dane miejsce zamarzło w pewnej chwili, tak jak to miałoby być z Pompejami w dniu 24 sierpnia 79 roku (por. Kadrow 1998). We wszystkich tych przypadkach czas się nie zatrzymał, on bezustannie płynie i zmienia owe krajobrazy. Czarnobyl widziany na archiwaliach z 1986 roku i na filmie prowadzonym przez J. Podemskiego to podobne miejsca, ale nie identyczne. Czas tutaj - by tak powiedzieć - raczej „Zwolnił” (por. Olsen 2013). To nie opuszczone, zapomniane krajobrazy. Wręcz odwrotnie, podlegają one ciągłym transformacjom. Dlatego też tak ważny dla polskiego widza wydaje się Czarnobyl - Wstęp Wzbroniony. Ukazuje on bowiem dziedzictwo katastrofy w konkretnym czasie, w pewnym stadium transformacji, heritage in the making (ryc. 7). Podobne zdanie można powiedzieć o miejskich eksploratorach, którzy dokumentują ruiny nowoczesności w Polsce, utrwalają oni „bycie” ruin w ciągłej zmianie.

Takie programy jak Wstęp Wzbroniony mają swoje pozytywne, ale również i negatywne aspekty. $Z$ jednej strony, wzrost społecznego zainteresowania

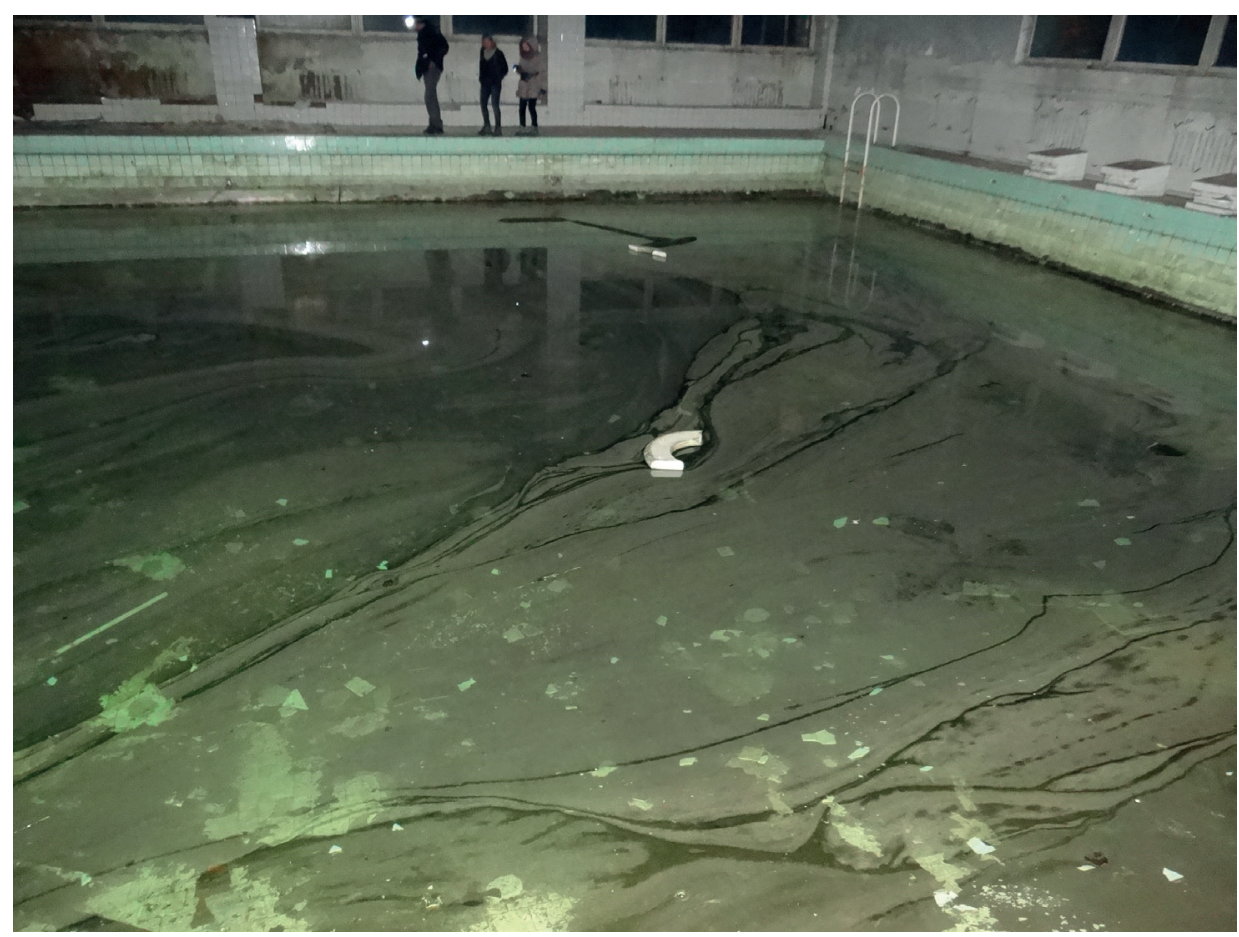

Ryc. 7. Dawny basen w szpitalu w Legnicy: jedno z najbardziej - by użyć języka Benjaminowskiego - „auratycznych” miejsc, w których miałem przyjemność być w trakcie miejskiej eksploracji (fot. D. Kobiałka). 
dziedzictwem ostatnich dekad jest procesem bez dwóch zdań pozytywnym. Ruiny nie są domeną odległej przeszłości. Są niemalże - by ująć to nieco metaforyczne - za każdym rogiem ulicy. Nawet, co szczególne ważne w kontekście ostatniej polityki historycznej uprawianej w naszym kraju, pozostałości sowieckie w Legnicy czy w Bornem Sulinowie to też wartościowe dziedzictwo niedawnej przeszłości, nierozerwalna część współczesnego krajobrazu Polski. Takie zainteresowanie pozostałościami nowoczesności może skutkować społecznymi działaniami zmierzającymi do rewitalizacji, ponownego wykorzystania danych przestrzeni, ochrony przed bezpowrotnym zrównaniem ich z powierzchnią ziemi.

$\mathrm{Z}$ drugiej jednak strony trzeba wspomnieć o zagrożeniach płynących z popularności m.in. Wstepu Wzbronionego. Program jest zrobiony w bardzo profesjonalny sposób. Widz wręcz doświadcza ,aury” danego miejsca, tak jakby był razem z prowadzącym w bunkrze w Międzyrzeckim Rejonie Umocnionym, czy też kilkaset metrów pod ziemią w kopalni uranu w Nowych Kowarach. Mimo, iż każdy odcinek zaczyna się od podkreślenia niebezpieczeństw, jakie ze sobą niosą miejsca eksploracji, to liczba miłośników urbexu będzie rosnąć. Część z nich niszczy, doprowadza do jeszcze większej dewastacji ruiny niedawnej przeszłości. Sam J. Podemski zabiera w jednym z odcinków zbitą, szklaną fiolkę z ruin niemieckiej fabryki materiałów wybuchowych. Jest to przecież takie samo materialne dziedzictwo, jak np. neolityczny fragment ceramiki. Niemniej jednak - mówiąc paradoksalnie - ruiny są ruinami, zniszczonymi i popadającymi w zapomnienie i degradację przestrzeniami. Niszczenie i transformacje są wpisane w „bycie” ruin. $Z$ tego punktu widzenia należy powiedzieć, iż nie tylko rzeczy i miejsca są częściami historii (archeologii) ludzi. To działa również w drugą stronę, ludzie są aktywnymi częściami, twórcami, współtwórcami archeologii danych miejsc. Dotyczy to także „miejskich eksploratorów”, którzy aktywnie zmieniają i współkreują dane opuszczone przestrzenie (ryc. 8). Ruinacja to składowa „bycia” ruiną.

\section{Podsumowanie}

Film Czarnobyl - Wstęp Wzbroniony dokumentuje to stanowisko mając na uwadze historyczną rolę oraz znaczenie tego miejsca dla ludzkości. Film A. Kurasza to archeologia współczesności w najlepszym wydaniu. Wątki historyczne, antropologiczne i zainteresowanie kulturą materialną i ruinami nowoczesności są kreatywnie wykorzystane. To dokument wręcz obowiązkowy dla badacza interesującego się XX-wiecznym dziedzictwem, rolą i znaczeniem ruin niedawnej przeszłości we współczesności. Film jest kolejnym dowodem tego, w jaki sposób materialne relikty niewyobrażalnej katastrofy ulegają przewartościowaniu, powoli stając się bezcennym dziedzictwem, które należy otoczyć pewną formą „troski”. 


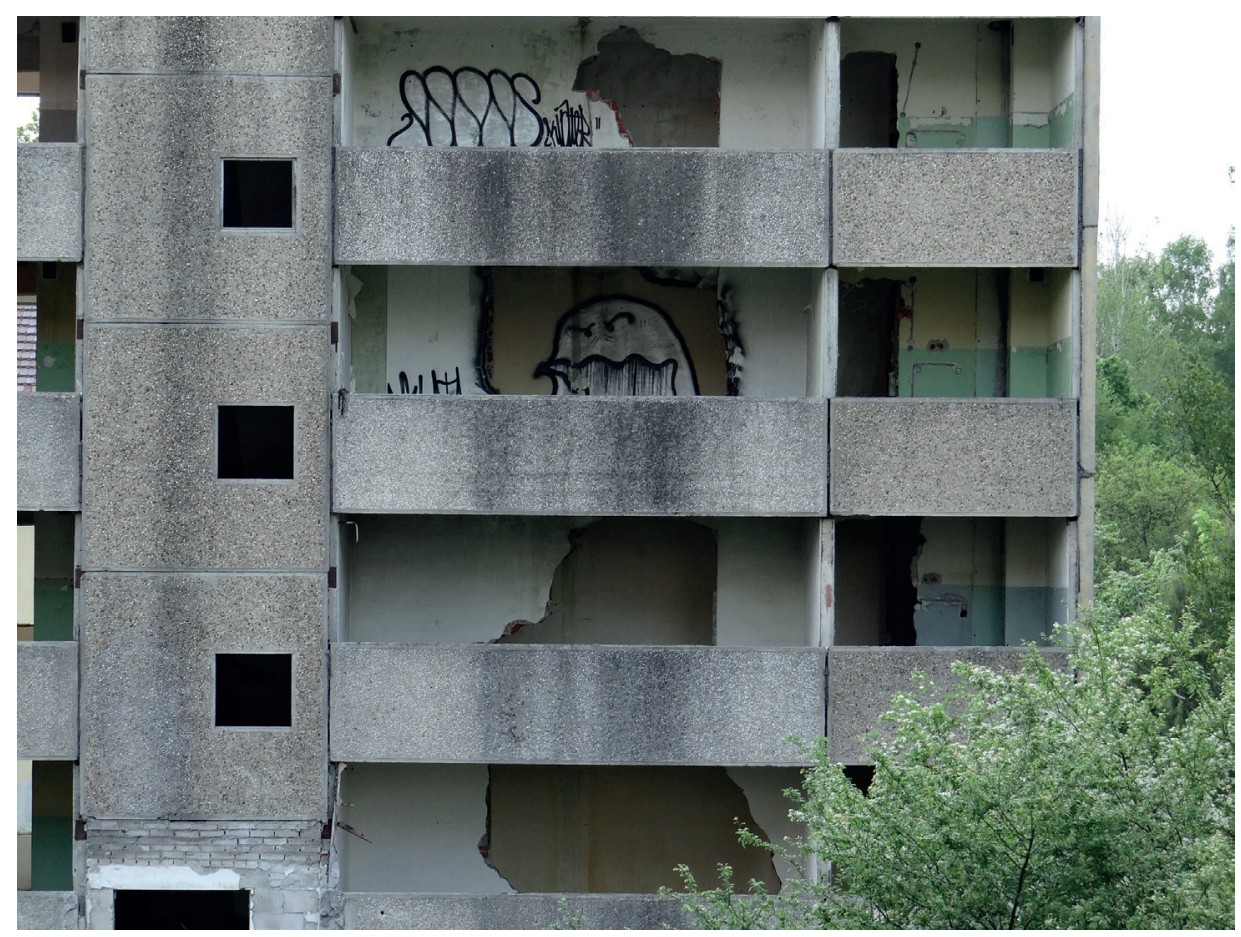

Ryc. 8. Kreacja nowego dziedzictwa w kontekście reliktów niedawnej przeszłości: „sztuka uliczna” na jednym ze zrujnowanych bloków w Kłominie (fot. D. Kobiałka).

Wybuch reaktora w bloku $4 \mathrm{w}$ Czarnobylu ma przynajmniej dwa wymiary. Pierwszy to ten związany z napromieniowaniem ludzi, rzeczy, miejsc i samej lokalnej przyrody; zapewne jedną z jego konsekwencji było zniszczenie bezcennych stanowisk archeologicznych. Drugi wymiar dotyczy faktu, iż sam Czarnobyl stał się „stanowiskiem archeologicznym”, niezwykłym sowieckim dziedzictwem lat 80. XX w. Już bowiem słychać głosy m.in. archeologów (por. Olivier 2013; Schlanger i in. 2016) argumentujących za postrzeganiem czarnobylskiej elektrowni jako „miejsca pamięci”.

Ruiny, relikty, dziedzictwo niedawnej przeszłości w pewnych kontekstach mogą być ważniejsze (wartościowsze) od tego pradziejowego, gdyż to pierwsze jest częścią nadal żywych wspomnień. Dla jeszcze wielu to fragment ich życia, część żywej pamięci. To w bardzo dosłownym znaczeniu „nasze dziedzictwo”. Tylko kwestią czasu jest wpisanie Czarnobyla na listę światowego dziedzictwa UNESCO. Było to wydarzenie, które miało globalny zasięg, a jego skutki lokalne społeczności będą odczuwały jeszcze tysiące lat, podobnie zresztą jak środowisko naturalne. Strefa Zero to - mówiąc krótko - wyjątkowe stanowisko (dziedzictwo) archeologiczne niedawnej przeszłości. 
Podsumowując, urbex jest formą doświadczania heritage in the making. To refleksja dotycząca physis samego dziedzictwa. W końcu, urbex to forma poszukiwań w zakresie archeologii współczesności.

Dawid Kobiałka

Instytut Archeologii i Etnologii PAN

e-mail: dawidkobialka@wp.pl

\section{Bibliografia}

Andreassen E., Bjerck H., Olsen B. (2010), Persistent memories. Pyramiden - a Soviet mining town in the High Arctic, Tapir Academic Press, Trondheim.

Andrusieczko P. (2016), Czarnobyl - 30 lat po, „Gazeta Wyborcza”, 25.04.2016, http:// wyborcza.pl/1,75399,19975452,czarnobyl-30-lat-po.html (dostęp: 1.02.2017).

Barriga T. (2015), Polskie miasta duchów, „TVN24”, 5.12.2015, http://www.tvn24.pl/ magazyn-tvn24-na-weekend/polskie-miasta-duchow,16,332 (dostęp: 1.02.2017).

Benjamin W. (2010), Pasaże, Wydawnictwo Literackie, Kraków.

Brooks E. (2016), Meet Chernobyl's only archaeologists. And he happens to be an Aussie, „The Huffington Post Australia”, 24.04.2016, http://www.huffingtonpost. com.au/2016/04/24/chernobyl-30-year-anniversary-archeology_n_9755996.htm1?utm_hp_ref=australia (dostęp: 1.02.2017).

Buchli V., Lucas G. (red.) (2001), Archaeologies of the contemporary past, Routledge, London-New York.

Dawdy S.L. (2010), Clockpunk anthropology and the ruins of modernity, „Current Anthropology", t. 51(6), s. 761-793.

Edensor T. (2005), Industrial ruins: space, aesthetics and materiality, Berd, OxfordNew York.

Fowler S. (2015), Writing collapse, [w:] G. Emberling (red.), Social theory in archaeology and ancient history: the present and future of counternarratives, Cambridge University Press, Cambridge, s. 205-230.

Gołębiowska M. (2015), Urbex po dolnośląsku. Adrenalina z doza rozsądku, „Gazeta Wyborcza" 20.01.2015, http://wroclaw.wyborcza.pl/wroclaw/1,35771,17284736,Urbex_po_dolnoslasku_Adrenalina_z_doza_rozsadku_WIDEO_html (dostęp: 1.02.2017).

Hanus K. (2015), Chronić i stużyć - zastosowanie dronów w projektach ochrony dziedzictwa archeologicznego, „Biografia Archeologii”, t. 1(1), s. 92-102.

Harman G. (2011), The quadruple object, John Hunt Publishing, Ropley.

Harraway D. (2003), The companion species manifesto: dogs, people, and significant otherness, University of Chicago Press, Chicago.

Harrison R., Schofield J. (2010), After modernity. Archaeological approaches to the contemporary past, Oxford University Press, Oxford.

Holtorf C., Piccini A. (red.) (2009), Contemporary archaeologies - excavating now, Peter Lang, Frankfurt am Main. 
Holtorf C., Högberg A. (2013), Heritage futures and the future of heritage, [w:] S. Bergerbrant, S. Sabatini (red.), Counterpoint: essays in archaeology and heritage studies in honour of professor Kristian Kristiansen, Archaepress, Oxford, s. 739-746.

Holtorf C., Högberg A. (2014), Communicating with future generations: what are the benefits of preserving cultural heritage, „European Journal of Post-Classical Archaeologies", t. 4, s. 315-330.

Kadrow S. (1998), „Przesłanka pompejańska” a badania archeologiczne $w$ Polsce - wybrane zagadnienia, „Zeszyty Ośrodka Ratowniczych Badań Archeologicznych. Seria A: Metody i zagadnienia prawne", t. 2a, s. 9-26.

Kajda, K., Kostyrko M. (2016), Contemporary dimension of heritage promotion - towards socially engaged archaeology, „Sprawozdania Archeologiczne”, t. 68, s. $9-23$.

Kobiałka D. (2014), Let heritage die! The ruins of trams at depot no. 5 in Wroctaw, Poland, „Journal of Contemporary Archaeology”, t. 1(2), s. 351-368.

Kobiałka D. (2016), UrbEx: archeologiczny flâneuryzm a multitemporalność dziedzictwa, „Biografia Archeologii”, t. 2(1), s. 3-12.

Kobiałka D., Kajda K., Frąckowiak F. (2015a), Archaeologies of the recent past and the Soviet remains of the Cold War in Poland: a case study of Brzeźnica-Kolonia, Kłomino and Borne Sulinowo, „Sprawozdania Archeologiczne”, t. 67, s. 9-22.

Kobiałka D., Frąckowiak M., Kajda K. (2015b), Tree memories of the Second World War: a case study of common beeches from Chycina, Poland, „Antiquity”, t. 89(345), s. 683-696.

Kusiak J. (2013), Walter Benjamin i metodologia antropologicznego materializmu. Krzesanie dialektycznych iskier na metalowej głowie Ernsta Thälmanna, „Praktyka Teoretyczna”, t. 2(8), s. 309-332.

Latour B. (2011), Nigdy nie byliśmy nowocześni, Oficyna Naukowa, Warszawa.

Oliphant R. (2016), Chernobyl disaster: On the 30th anniversary of the nuclear accident, authorities plan for the next century, ,The Telegraph”, 26.04.2016, http:// www.telegraph.co.uk/news/2016/04/26/chernobyl-anniversary-30-years-afterits-nuclear-disaster-author/ (dostęp: 1.02.2017).

Olivier L. (2011), The dark abyss of time: archaeology and memory, Altamira Press, Lanham, DC.

Olivier L. (2013), The business of archaeology is in the present, [w:] A. González-Ruibal (red.), Reclaiming archaeology. Beyond the tropes of modernity, Routledge, London, s. 117-129.

Olsen B. (2013), W obronie rzeczy. Archeologia i ontologia przedmiotów, Wydawnictwo Instytutu Badań Literackich PAN, Warszawa.

Olsen B., Pétursdóttir P. (red.) (2014), Ruin memories: materialities, aesthetics and the archaeology of the recent past, Routledge, Abingdon-New York.

Paiva T. (2008), Night vision: the art of urban exploration, Chronicle Books, San Francisco. 
Pajewska A. (2014), Urbex - ta zabawa nie jest dla dziewczynek? FOCH!, http://foch. pl/foch/1,132037,16035104,Urbex__ta_zabawa_nie_jest_dla_dziewczynek_. html (dostęp: 1.02.2017).

Pétursdóttir P. (2012a), Concrete matters: ruins of modernity and the things called heritage, „Journal of Social Archaeology”, t. 13(1), s. 31-53.

Pétursdóttir P. (2012b), Small things forgotten now included, or what else do things deserve?, „International Journal of Historical Archaeology”, t. 16(3), s. 577-603.

Pétursdóttir P., Olsen B. (2014), An archaeology of ruins, [w:] B. Olsen, P. Pétursdóttir (red.), Ruin memories: materialities, aesthetics and the archaeology of the recent past, Routledge, Abingdon-New York, s. 3-29.

Schlanger N., Nespoulous L., Demoule J-P. (2016), Year 5 at Fukushima: a 'disaster-led' archaeology of the contemporary future, „Antiquity”, t. 90(350), s. 409-424.

Shanks M. (2012), The archaeological imagination, Left Coast Press, Walnut Creek.

Witmore C. (2014), Archaeology and the new materialisms, „Journal of Contemporary Archaeology", t. 1(2), s. 203-224.

Wstęp Wzbroniony (2015), „TVN Turbo”, http://www.tvnturbo.pl/programy/wstep-wzbroniony, 10994.html (dostęp: 1.02.2017).

\section{SUMMARY}

\section{RUINS, RUINS EVERYWHERE: \\ CHERNOBYL AND AN ARCHAEOLOGICAL VALUE OF HERITAGE OF THE RECENT PAST}

For many centuries, scientists, philosophers, artists and others have been fascinated with ruins. However, this fascination usually focused upon ancient and medieval relics. Indeed, it can be metaphorically said that archaeology was built upon ruins.

Nonetheless, the archaeological analyses of ruins, their functions, meanings, uses and re-uses over the next centuries had been very selective. In short, modern ruins have been out of closer archaeological attention. It seems as if modern ruins were deprived of social, cultural, and archaeological dimensions. However, this changed during the first decade of the 21 st century when archaeologists started to pay attention to the modern ruins. The so-called archaeology of (modern) ruins is one of the most interesting, provocative, and subversive fields of the contemporary archaeological discourses.

The starting point of this paper is that there is no "ontological difference" between the Greek, the Roman and the Soviet ruins. All of them can and should be part of archaeological thinking. A two-step approach is applied here.

First, the archaeological value of ruins in Chernobyl is discussed. A documentary entitled Czarnobyl - Wstęp Wzbroniony (2015) (Eng. Chernobyl - No Entry) is reviewed 
to highlight the processes of transformation of the unimaginable nuclear catastrophe into valuable heritage of the recent past. It is argued that Chernobyl can be seen as "Pompeii of our times".

Second, the review of Czarnobyl - Wstep Wzbroniony is used as a pretext to shortly present different categories of modern ruins that one can encounter in contemporary Poland. Many of them are related with the Soviet occupation in Poland between 1945 and 1993. The point that I try to back up in this paper is that these Soviet ruins are also part of the archaeological heritage of the recent past. Accordingly, this paper is a call for a closer archaeological interest in the ruins of the recent past in general. 